ISBN 978-93-84422-79-0

7th International Conference on Business, Education, Law, and Sustainable Development

(BELSD-17)

Singapore Aug.10-11, 2017

\title{
Exploring the Combinations of Conditions Affecting the Successful ODA Projects to Developing Countries
}

\author{
Young-Chool $\mathrm{Choi}^{1}$ and Hak-Sil Kim ${ }^{2}$ \\ ${ }^{1}$ Professor, Chungbuk National University, Korea \\ ${ }^{2}$ Assistant Professor, Chunabuk National University, Korea \\ Email id: ycchoi@cbu.ac.kr
}

\begin{abstract}
Since 2010 when Korea became a member country of the OECD DAC (Development Assistance Committee), Korea has provided assistance on various socio-economic developments to countries such as Vietnam, Laos, Sri Lanka etc. by funding aids through from both provincial as well as territorial sources along with international global sources. However, it is generally accepted that mixed results have been made up until now due to many factors like inefficient providing system, corruption of the recipient countries, and the prevalent political system which has made its aid delivery measures highly unnoticed and incompetent at the present temporal context. Under this background, this paper attempts to discover the combinations of conditions affecting the successful ODA projects to developing countries using the cases of the ODA projects conducted by the Korean government. In addition, this article attempts to explore the ways in which the policy might effectively be transferred to other countries, and seeks to put forward suggestions beneficial to policymakers and practitioners involved with the policy in Korea. In doing so, this research employs the Qualitative Comparative Analysis (QCA) method to discover the conditions affecting the successful implementation of the ODA projects.
\end{abstract}

Keywords: ODA projects, policy transfer, QCA.

\section{Introduction}

The Republic of Korea government was established for the first time in 1948, following 36 years of Japanese colonial rule. In 1948, the per capita GDP of South Korea was 50 US dollars, the lowest in the world, and the illiteracy rate was almost 80 per cent. However, in 2015, Korea's per capita GDP was 27,221 US dollars, and the country was ranked twelfth in the world in terms of economic power. Also, in 2010 Korea became a member country of the OECD Development Assistance Committee (DAC), its track record as recipient-turned-donor over a period of less than a century meaning that it became the first country to develop from aid recipient to aid provider when it joined the 23-member DAC. This case is exceptional and almost unprecedented. Since 2010 Since 2010 when Korea became a member country of the OECD DAC (Development Assistance Committee), Korea has provided assistance on various socio-economic developments to countries such as Vietnam, Laos, Sri Lanka etc. by funding aids through from both provincial as well as territorial sources along with international global sources. However, it is generally accepted that mixed results have been made up until now due to many factors like inefficient providing system, corruption of the recipient countries, and the prevalent political system which has made its aid delivery measures highly unnoticed and incompetent at the present temporal context. Under this background, this paper attempts to discover the combinations of conditions affecting the successful ODA projects to developing countries using the cases of the ODA projects conducted by the Korean government. In addition, this article attempts to explore the ways in which the policy might effectively be transferred to other countries, and seeks to put forward suggestions beneficial to policymakers and practitioners involved with the 
policy in Korea. In doing so, this research employs the Qualitative Comparative Analysis (QCA) method to discover the conditions affecting the successful implementation of the ODA projects.

\section{Literature Review and Research Questions}

\subsection{ODA Projects and theirs importance}

ODA (Official Development Assistance) is primarily concerned with DAC projects which are aimed to assist developing countries and are provided by the OECD (Organisation for Economic Co-operation and Development). It can be both bilateral as well as multilateral. The ODA authorities in Korea aim to help developing countries with supplies, civil engineering and other assistance (Das and Das, 2013). As noted earlier, in 2010 Korea became a member of the OECD's Development Assistance Committee (DAC), a forum for discussing issues surrounding aid, development, and poverty reduction in developing countries. This means that Korea is the only country in the world that was a recipient of assistance in the past to have become now a donor country. In fact, in the 1950s, around half of the Korean government's budget was made up of foreign aid, without which it could not have sustained itself financially, but Korea is now one of the world's ten largest economies. This implies that it is no exaggeration to say that Korea's experiences with ODA projects can draw special attention from other ODA donor and recipient countries as well.

\subsection{Factors affecting Successful ODA projects}

Since ODA is basically a type of policy transfer, it is necessary to research approaches to policy transfer in order to discover the factors affecting ODA projects. Theoretically, there are several diverse approaches to policy transfer. Policy transfer and policy diffusion are terms that are now commonly used within political studies and policy analysis. Although definitions vary, policy transfer is widely understood as 'a process by which knowledge of policies, administrative arrangements, institutions and ideas in one political system (past or present)' is used in the development of similar features in one political system (Dolowitz, 2000: 3; Benson and Jordan, 2011: 366). The policy transfer literature builds on previous work concerning lesson drawing (Greener, 2002; Rose, 1991, 1993) while policy diffusion literature often refers to quantitative work on the diffusion of innovations and program adoption (Coleman et al., 1966; Walker, 1969; Collier and Messick, 1975; Rogers, 1995; Obinger et al., 2013). This article focuses primarily on policy transfer, since 1 ODA projects are more closely related to this. It then asks what factors enable and constrain policy transfer? Dolowitz and Marsh (1996) identified several potential constraints relating to the inherent complexity of some policy programs. These included: path dependency arising from past decisions; institutional and structural impediments; a lack of ideological compatibility between transferring countries; and insufficient technological, economic, bureaucratic and political resources on the part of the receiving country to implement the transferred policies.

Evans (2009: 249) conceptualizes the constraints affecting policy transfer according to four types: demand side; programmatic; contextual; and application-related. As regards the demand side, policymakers are often unwilling to move beyond the status quo unless forced to by unexpected shocks such as the huge failure of an existing policy or a global economic crisis (Stone, 1999; Benson, and Jordan, 2011). Constraints then emerge over the specific programmatic characteristics of the policy (Page, 2000: 2). Here, the inherent 'uniqueness' of policies (Rose, 1993: 118; Benson and Jordan, 2011: 372) and their 'wider social and policy context' (Dolowitz, 2003: 106) can reduce their transferability. Exporter constraints are then mediated through contextual factors

related to the 'importer jurisdiction' (Page, 2002: 2), such as path dependency or policy layering (Benson and Jordan, 2011: 372). Lastly, application constraints include the high transaction costs of institutional adjustment, the scales of domestic change required, and whether policies themselves must undergo modifications to ensure successful transfer (Marsh and Sharman, 2009). Crucially, these factors will shape whether policies do in fact successfully transfer. 
In the meantime, the Department for International Department (DFID) in the UK suggests that Political Economy Analysis (PEA) should be applied in ODA projects. Here, PEA includes three level of analysis: macro-level country analysis; sector-level analysis; and problem-driven analysis (Department for International Department, 2009). DFID argues that problem-driven analysis should be conducted especially when implementing ODA projects as a policy transfer. Here, problem-driven analysis is similar to the 'programmatic' characteristics of policy as defined by Page (2000). Problem-driven analysis includes analysis of the factors associated with specific features affecting the success of the policy or project at issue. For this reason, this research is based upon DFID's problem-driven analysis level. In this regard, the factors to be considered in the analysis of ODA projects to be studied are characteristics which ODA projects initiated by Korean government have had since its inception. The basic characteristics maintained by Korean government as general governing principles are:

- Residents should be trained to change their attitude and mind-set, so that they become independent and so do not simply rely on government or on someone else to improve their lives.

- Community organization should be established, so that residents can participate in solving their common problems.

- Residents should nominate someone to take a lead in fostering the development of their community. This leader should be well-trained, and committed to developing their village or community.

- A job-related training program for residents should be created when implementing Korean government-initiated ODA projects.

- Profit-making tasks and businesses for recipients should be set up (Choi, 2013).

In theory, in order for Korean government-initiated ODA projects to be successfully implemented in developing countries as a policy transfer, the above-mentioned five criteria should apply. In reality, however, some ODA projects have been implemented with only two or three criteria, and some without any. Whether a given project has been implemented with or without these criteria may have a bearing on its degree of success.

On the basis of the factors outlined above, this study raises the following research question. What combinations of independent variables can make Korean government-initiated ODA projects successful at the sites?

\section{Research Design}

\subsection{Variables}

The projects to be included in this analysis consist of 30 designated ODA projects implemented by the Korean government between 2010 and 2014 in developing countries. Of these, five have been excluded because of problems with data. The variables analyzed in this research consist of five independent variables and one dependent variable. The five independent variables are: Spirit, Organization, Leader, Training, and Profit. The one dependent variable is Success. Spirit refers to whether recipients were given mind-set-('spirit') changing education or not when the ODA project was implemented. Organization means whether recipients had a community organization in which they could actively participate for the purpose of solving common or community issues when the project was implemented. Leader means whether recipients had a community leader who was trained and educated in the ODA project processes, etc., when the project was implemented. Training means whether recipients had a job-related training program, and Profit means whether recipients were given profit-making opportunities when the project was implemented. Success as a dependent variable means whether the project was successful or not in terms of sustainability. The judgment as to whether a project was successful or not is based on the analysis result contained in each project report conducted by the Korea International Cooperation Agency (KOICA), which is an agency in charge of ODA projects in Korea. KOICA, which is a non-departmental public organization, performs an evaluation study for each ODA project on a yearly basis, and publishes an analysis report for each project. The analysis results for the projects are employed here as a means whereby we can judge whether each project has been successful. 
Table I Sets out the Names of the Variables, their Measurement, and their Data Source.

TABLE I: Variables for QCA and Data Source

\begin{tabular}{|c|c|c|c|}
\hline VARIABLES & & DATA SOURCE & REMARKS \\
\hline SPIRIT & $\begin{array}{l}\text { WHETHER RECIPIENTS RECEIVED } \\
\text { ATTITUDE- AND MIND-SET-CHANGING } \\
\text { EDUCATION }\end{array}$ & & \\
\hline ORGANIZATION & $\begin{array}{l}\text { WHETHER RECIPIENTS' COMMUNITY } \\
\text { ORGANIZATIONS DECIDED ON } \\
\text { PROJECT IMPLEMENTATION }\end{array}$ & & \\
\hline LEADER & $\begin{array}{l}\text { WHETHER A RECIPIENT LEADER WAS } \\
\text { SELECTED AND CARRIED OUT THEIR } \\
\text { ROLE }\end{array}$ & $\begin{array}{c}\text { PROJECT ANALYSIS REPORTS BY KOICA AND OTHER } \\
\text { INSTITUTIONS }\end{array}$ & $\begin{array}{c}1 \text { OR } 0 \\
(0=\text { RESULT IS } \\
\text { POSITIVE; } 1= \\
\text { RESULT IS }\end{array}$ \\
\hline TRAINING & $\begin{array}{l}\text { WHETHER A TECHNOLOGY TRAINING } \\
\text { PROGRAM FOR FOSTERING } \\
\text { RECIPIENTS' INDEPENDENCE EXISTED }\end{array}$ & & NEGATIVE) \\
\hline PROFIT & $\begin{array}{l}\text { WHETHER PROFIT-MAKING TASKS } \\
\text { FOR RECIPIENTS EXISTED }\end{array}$ & & \\
\hline SUCCESS & $\begin{array}{l}\text { WHETHER THE SAEMAUL ODA } \\
\text { PROJECT WAS SUCCESSFUL }\end{array}$ & & \\
\hline
\end{tabular}

\subsection{Methods}

As the data used in this study include 25 cases, conventional quantitative methods are difficult to apply given such a small $\mathrm{N}$ research design. Table 2 presents simple explanations of the projects included in the analysis.

TABLE II: Explanations of the Projects Included in the Analysis

\begin{tabular}{|c|c|c|c|c|}
\hline PROJECT & $\begin{array}{l}\text { RECIPIENT } \\
\text { COUNTRY }\end{array}$ & $\begin{array}{l}\text { CLOSED/ } \\
\text { ONGOING }\end{array}$ & $\begin{array}{l}\text { PROJECT } \\
\text { PERIOD }\end{array}$ & TARGET \\
\hline P1 & LAOS & ONGOING & 2014-2018 & $\begin{array}{c}\text { RURAL } \\
\text { DEVELOPMENT }\end{array}$ \\
\hline P2 & LAOS & Closed & $2007-2008$ & $\begin{array}{c}\text { RURAL } \\
\text { DEVELOPMENT }\end{array}$ \\
\hline P3 & VIETNAM & ONGOING & 2014-2017 & $\begin{array}{l}\text { SAEMAUL } \\
\text { PROJECT }\end{array}$ \\
\hline P4 & VIETNAM & ONGOING & 2014-2017 & $\begin{array}{l}\text { SAEMAUL } \\
\text { PROJECT }\end{array}$ \\
\hline P5 & VIETNAM & Closed & 2001-2002 & $\begin{array}{c}\text { SAEMAUL PILOT } \\
\text { PROJECT }\end{array}$ \\
\hline P6 & CAMBODIA & ONGOING & 2014-2018 & $\begin{array}{c}\text { RURAL } \\
\text { DEVELOPMENT }\end{array}$ \\
\hline P7 & CAMBODIA & Closed & $2007-2008$ & $\begin{array}{c}\text { RURAL } \\
\text { DEVELOPMENT }\end{array}$ \\
\hline P8 & CAMBODIA & Closed & 2006-2008 & $\begin{array}{c}\text { RURAL } \\
\text { DEVELOPMENT }\end{array}$ \\
\hline P9 & CAMBODIA & Closed & 2010-2012 & $\begin{array}{c}\text { RURAL } \\
\text { DEVELOPMENT }\end{array}$ \\
\hline P10 & PHILIPPINES & ONGOING & 2013-2016 & $\begin{array}{c}\text { RURAL } \\
\text { DEVELOPMENT }\end{array}$ \\
\hline P11 & MYANMAR & ONGOING & 2014-2019 & $\begin{array}{c}\text { RURAL } \\
\text { DEVELOPMENT }\end{array}$ \\
\hline P12 & MYANMAR & Closed & $2008-2010$ & $\begin{array}{c}\text { RURAL } \\
\text { DEVELOPMENT }\end{array}$ \\
\hline
\end{tabular}




\begin{tabular}{|c|c|c|c|c|}
\hline P13 & DR CONGO & ONGOING & $2013-2017$ & $\begin{array}{c}\text { RURAL } \\
\text { DEVELOPMENT }\end{array}$ \\
\hline P14 & DR CONGO & CLOSED & 2010-2013 & $\begin{array}{c}\text { RURAL } \\
\text { DEVELOPMENT }\end{array}$ \\
\hline P15 & RWANDA & ONGOING & 2013-2017 & $\begin{array}{c}\text { RURAL } \\
\text { DEVELOPMENT }\end{array}$ \\
\hline P16 & RWANDA & ONGOING & 2014-2018 & $\begin{array}{c}\text { SAEMAUL PILOT } \\
\text { PROJECT }\end{array}$ \\
\hline P17 & ETHIOPIA & ONGOING & 2013-2018 & $\begin{array}{c}\text { RURAL } \\
\text { DEVELOPMENT }\end{array}$ \\
\hline P18 & ETHIOPIA & Closed & 2010-2012 & $\begin{array}{c}\text { RURAL } \\
\text { DEVELOPMENT }\end{array}$ \\
\hline P19 & SENEGAL & ONGOING & 2013-2017 & $\begin{array}{c}\text { RURAL } \\
\text { PRODUCTIVITY }\end{array}$ \\
\hline P20 & SENEGAL & ONGOING & 2014-2017 & $\begin{array}{c}\text { AGRICULTURAL } \\
\text { SCHOOL }\end{array}$ \\
\hline P21 & ECUADOR & ONGOING & 2014-2016 & $\begin{array}{l}\text { AGRICULTURAL } \\
\text { TECHNOLOGY }\end{array}$ \\
\hline P22 & PERU & Closed & 2010-2012 & $\begin{array}{c}\text { RURAL } \\
\text { DEVELOPMENT }\end{array}$ \\
\hline P23 & AFGHANISTAN & Closed & 2003-2004 & $\begin{array}{c}\text { RURAL } \\
\text { DEVELOPMENT }\end{array}$ \\
\hline P24 & MONGOL & Cloosed & $2008-2010$ & $\begin{array}{l}\text { AGRICULTURAL } \\
\text { PLANNING }\end{array}$ \\
\hline P25 & BANGLADESH & Cloosed & 2007-2010 & $\begin{array}{c}\text { RURAL } \\
\text { DEVELOPMENT }\end{array}$ \\
\hline
\end{tabular}

As Table II shows, most of the recipient countries are developing countries in Asia, Africa and South America. About half of the projects are already closed and another half are being implemented. Most of the projects are related to rural areas, including rural development and agriculture. The number of the projects used in the analysis is relatively small, so the QCA method can be employed properly.

\section{Analysis Results}

\subsection{Dichotomization}

Table II shows the dichotomized value ( 0 or 1$)$ of each variable. Here, as indicated above, 1 means positive (present) whereas 0 means negative (absent). For example, in the case of p1 (project 1) in Table II, 1 in the variable Spirit means that recipients (normally residents) involved in project 1 (p1) received attitude- and mindset-changing education in the implementation process of the project, while in the case of $\mathrm{p} 2,0$ in the variable Spirit means that recipients did not receive that education during the implementation process. Likewise, 25 projects which were implemented by the Korean government between 2010 and 2014 in developing countries including Cambodia, Vietnam and Ethiopia were dichotomized by according the value 1 or 0 to each variable. A rationale for this is provided by Rihoux (2006), who notes that 'QCA is in essence a case sensitive approach', where 'the use of QCA is an iterative and creative process'. With values of [0] and [1] having been assigned to the successful policy transfer conditions, the projects' outputs can then be classified on the basis of the performance report for each project, resulting in a dichotomization table (Table III) 
TABLE III: Dichotomization of variables by 1 or 0

\begin{tabular}{ccccccc}
\hline \hline PROJECT & SPIRIT & ORGANIZATION & LEADER & TRAINING & PROFIT & SUCCESS \\
\hline P1 & 1 & 1 & 1 & 1 & 1 & 1 \\
P2 & 0 & 0 & 0 & 1 & 0 & 0 \\
P3 & 1 & 1 & 1 & 1 & 1 & 1 \\
P4 & 1 & 1 & 1 & 0 & 1 & 1 \\
P5 & 1 & 0 & 1 & 0 & 1 & 1 \\
P6 & 1 & 1 & 1 & 1 & 1 & 1 \\
P7 & 0 & 0 & 1 & 1 & 0 & 1 \\
P8 & 1 & 1 & 1 & 1 & 1 & 1 \\
P9 & 1 & 1 & 1 & 1 & 1 & 1 \\
P10 & 0 & 0 & 1 & 1 & 1 & 1 \\
P11 & 0 & 1 & 1 & 1 & 1 & 1 \\
P12 & 1 & 1 & 1 & 1 & 1 & 1 \\
P13 & 0 & 1 & 1 & 1 & 1 & 0 \\
P14 & 0 & 0 & 0 & 0 & 1 & 0 \\
P15 & 1 & 1 & 1 & 1 & 1 & 1 \\
P16 & 1 & 1 & 1 & 1 & 1 & 1 \\
P17 & 1 & 0 & 1 & 1 & 1 & 1 \\
P18 & 0 & 1 & 1 & 1 & 1 & 1 \\
P19 & 0 & 0 & 1 & 1 & 0 & 1 \\
P20 & 0 & 0 & 1 & 1 & 0 & 1 \\
P21 & 0 & 0 & 1 & 1 & 0 & 1 \\
P22 & 0 & 0 & 0 & 1 & 1 & 0 \\
P23 & 0 & 0 & 1 & 0 & 0 & 0 \\
P24 & 0 & 0 & 0 & 1 & 1 & 0 \\
P25 & 1 & 1 & 1 & 0 & 1 & 0 \\
\hline \hline
\end{tabular}

\subsection{Truth Table Analysis}

With values of [0] and [1] having been assigned, 25 ODA projects can then be recorded, resulting in a truth table (Table 4). Qualitative Comparative Analysis focuses on the construction and minimization of truth tables. The truth table lists every unique configuration of independent variables found in the data, along with the number of 0,1 , and don't-care (-) cases associated with the configuration. The value of the dependent variable for a configuration is a function of the distribution of 0,1 and don't-care cases. If a configuration occurs in the data with both 0 and 1 values on the dependent variable, QCA treats it as a contradiction and assigns to the dependent variable the value $\mathrm{C}$. Otherwise, QCA assigns to the dependent variable for a configuration the value 0 (only 0 and don't-care cases exist), 1 (only 1 and don't-care cases exists), or - (only don't-care cases exist). 
TABLE IV: Truth Table Analysis

\begin{tabular}{|c|c|c|c|c|c|c|}
\hline $\begin{array}{l}\text { v1: } \\
\text { v3: } \\
\text { v5: }\end{array}$ & $\begin{array}{l}\text { spirit } \\
\text { leader } \\
\text { profit }\end{array}$ & $\begin{array}{l}\vee 2: \\
\vee 4:\end{array}$ & \multicolumn{3}{|c|}{$\begin{array}{l}\text { organization } \\
\text { training }\end{array}$} & \\
\hline O: & \multicolumn{2}{|c|}{ success } & id: & \multicolumn{2}{|c|}{ CASE } & \\
\hline v1 & $\mathrm{v} 2$ & v3 & $\vee 4$ & v5 & $\mathrm{O}$ & id \\
\hline 1 & 1 & 1 & 1 & 1 & 1 & $\mathrm{P} 1, \mathrm{p} 3, \mathrm{p} 6, \mathrm{p} 8, \mathrm{p} 9, \mathrm{p} 12, \mathrm{p} 15, \mathrm{p} 16$ \\
\hline 0 & 0 & 0 & 1 & 0 & 0 & $p^{2}$ \\
\hline 1 & 1 & 1 & 0 & 1 & $\mathrm{C}$ & $p 4, p 25$ \\
\hline 1 & 0 & 1 & 0 & 1 & 1 & p5 \\
\hline 0 & 0 & 1 & 1 & 0 & 1 & p7,p19,p20,p21 \\
\hline 0 & 0 & 1 & 1 & 1 & 1 & p10 \\
\hline 0 & 1 & 1 & 1 & 1 & $\mathrm{C}$ & $\mathrm{p} 11, \mathrm{p} 13, \mathrm{p} 18$ \\
\hline 0 & 0 & 0 & 0 & 1 & 0 & p14 \\
\hline 1 & 0 & 1 & 1 & 1 & 1 & p17 \\
\hline 0 & 0 & 0 & 1 & 1 & 0 & $\mathrm{p} 22, \mathrm{p} 24$ \\
\hline 0 & 0 & 1 & 0 & 0 & 0 & p23 \\
\hline
\end{tabular}

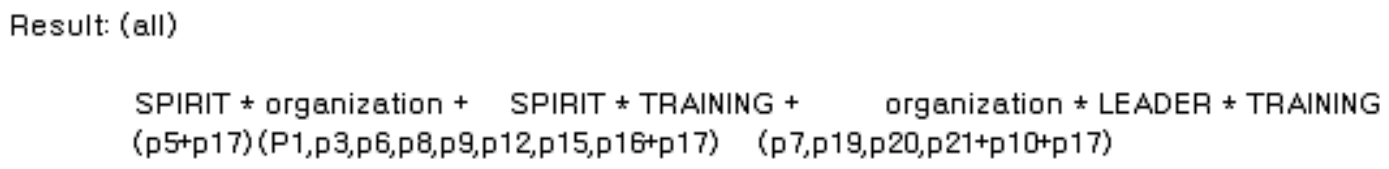

In a truth table produced using the TOSMANA 1.3 program, various conditions can be compared against each other and, ideally, against an outcome, the ODA project's success. Venn diagrams illustrate the logical relationships between conditions. Each space in a diagram can be color coded, shaded or patterned. Figure 1 is a graphical depiction of the configurations from the truth values presented in Table 4 and was produced by TOSMANA 1.3's 'visualizer' tool.

Table V shows that there five configurations leading to the success of the ODA projects. Sufficient condition 1 is a condition in which, upon a project being implemented, mind-set-changing efforts are made by recipients; a community organization exists; a project leader (community leader) exists; a job-related training program exists; and a profit-making business opportunity exists. The projects fulfilling sufficient condition 1 are p1, p3, p6, p8, p9, p12, p15, and p16. As was shown in Table 4, sufficient conditions ranging from 2 to 5 have different combinations of variables leading to the success of projects.

TABLE V: Combinations Bringing About the Success of Saemaul ODA Project Implementation

\begin{tabular}{|c|c|c|c|c|c|c|}
\hline CONDITIONS & SPIRIT & ORGANIZATION & LEADER & TRAINING & PROFIT & ProjeCts \\
\hline $\begin{array}{l}\text { SUFFICIENT } \\
\text { CONDITION } 1\end{array}$ & 1 & 1 & 1 & 1 & 1 & $\begin{array}{c}\mathrm{P} 1,3,6,8,9 \\
12,15,16\end{array}$ \\
\hline $\begin{array}{l}\text { SUFFICIENT } \\
\text { CONDITION } 2\end{array}$ & 1 & 0 & 1 & 0 & 1 & P5 \\
\hline $\begin{array}{c}\text { SUFFICIENT } \\
\text { CONDITION } 3\end{array}$ & 0 & 0 & 1 & 1 & 0 & $\mathrm{P} 7,19,20,21$ \\
\hline $\begin{array}{l}\text { SUFFICIENT } \\
\text { CONDITION } 4\end{array}$ & 0 & 0 & 1 & 1 & 1 & P10 \\
\hline $\begin{array}{c}\text { SUFFICIENT } \\
\text { CONDITION } 5\end{array}$ & 1 & 0 & 1 & 1 & 1 & P17 \\
\hline
\end{tabular}




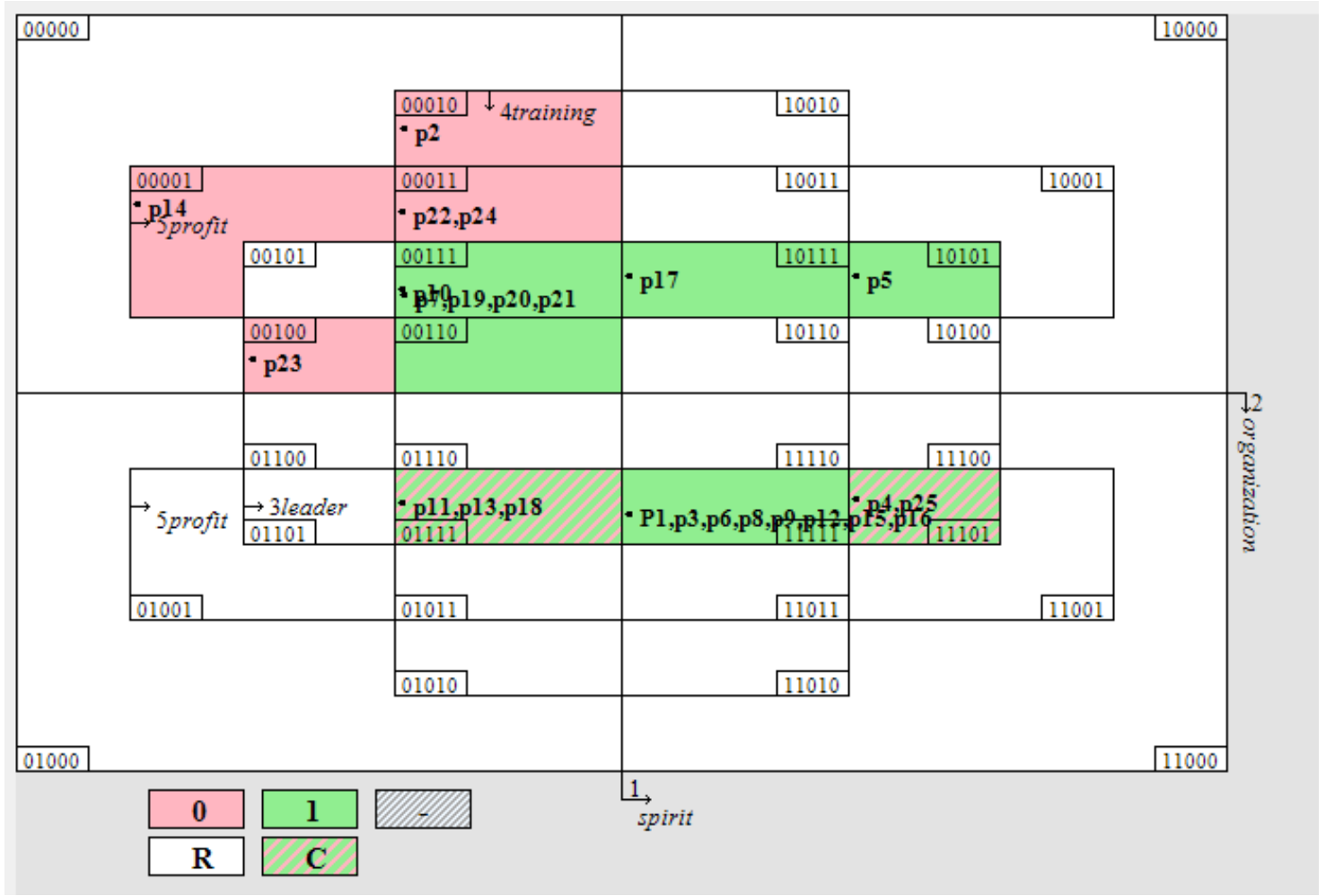

Fig.1: Venn diagram showing the success of Saemaul ODA projects

In Figure 1, [1], or a positive outcome, is shaded green; [0], or a negative outcome, is shaded lilac; and [C], or contradictory configurations, are patterned with green and lilac stripes, Contradictory configurations occur in cases where some combinations of conditions result in a [0] outcome but others result in a [1] outcome (Wiechula, 2012). Blank white spaces are logical remainders [R], or combinations of conditions that have not been observed. For example, in the lower left space the notation 01000 highlights the absence of any combination of conditions associated with a positive outcome. Table IV and Figure 1 show five configurations associated with the success of the ODA projects.

Again, Table IV shows that there are five configurations explaining the successful implementation of the ODA projects. Here, uppercase letters indicate a value of 1 (positive), and lowercase a value of 0 (negative). As Table 5 shows, in this analysis three prime implicants explaining the successful implementation of the ODA projects are found. A prime implicant is usually a set of conditions joined by the Boolean 'AND' [*] operator, suggesting a relationship or solution between the conditions (Donnelly, 2013: 11). Because 'prime implicant' means the most minimal solution minimizing truth table results, in this analysis three prime implicants can provide useful information for policymakers and practitioners. In other words, the conditions SPIRIT*organization, SPIRIT*TRAINING, and Organization*LEADER*TRAINING are called the prime implicants of the five configurations produced. In sum, these three prime implicants are combinations of important conditions determining the successful implementation of Korean ODA projects implemented in developing countries.

TABLE V : Prime Implicants

\begin{tabular}{ccc}
\hline \hline PRIME IMPLICANTS & PROJECT & REMARK \\
\hline SPIRIT*ORGANIZATION & P5,P17 & 2 \\
SPIRIT*TRAINING & P1,P3,P6,P8,P9,P12 & 9 \\
& P15,P16,P17 & 1 \\
ORGANIZATION*LEADER*TRAINING & P7,P19,P20,P21,P10,P17 & 1 \\
\hline \hline
\end{tabular}


In other words, there are three important combinations of conditions affecting the successful transfer of the ODA projects to developing countries. The first is the combination of SPIRIT*organization, which means that recipients of the ODA project received attitude- and mindset-changing education in the implementation process of the project and there was no community organization which decided on project implementation. The second combination of conditions is SPIRIT*TRAINING, meaning that recipients of the ODA project received attitudeand mindset-changing education in the implementation process of the project, and also that a technology training program for fostering recipients' independence existed. Finally, the third combination is Organization*LEADER*TRAINING, meaning that recipients' community organizations decided on project implementation, a recipient leader was selected and carried out their role in the implementation process, and a technology training program for fostering recipients' independence existed in the project implementation process.

What does this result mean to policymakers in the donor and recipient countries? Firstly, Korea, as a donor country, needs to pay more attention to the three combinations of conditions, checking each ODA project prior to its implementation to ascertain whether the project is equipped with a suitable training programme and leadership programme, etc., as suggested in Table 5, and monitoring to ensure that these conditions are met without difficulty, and so on. Secondly, it is also necessary for the recipient countries to support the Korean government in its efforts to implement these projects at site, with a focus on the establishment of the appropriate conditions. It is also important that we understand that one of the three combinations of conditions may be enough to make a ODA project successful in terms of its implementation in developing countries; this means that one of the three conditions, for example SPIRIT*TRAINING, is sufficient in order for the Korean government to successfully implement the projects in developing countries, rather than the Korean government needing to meet all three conditions for the successful transfer of the ODA projects. Hence it can be said that policymakers involved in ODA projects have more policy flexibility in designing and implementing the projects, in the sense that they can pay attention to whether a given ODA project is being implemented with one of the three combinations rather than with all three.

\section{Conclusion}

This article emphasizes the importance of conditions affecting the successful implementation of the ODA projects in developing countries, describes the usefulness of QCA in examining which causal conditions can influence the successful implementation of the ODA projects as a policy transfer, and attempts to discover configurations associated with successful ODA projects and simple prime implicants relating to the solution. In this analysis, five configurations affecting successful ODA projects and three prime implicants (namely sets of conditions suggesting a relationship or solution between the conditions) were derived. QCA is an alternative approach to the analysis of ODA projects as a policy transfer which involves truth tables, Boolean algebra, and the search for a greater understanding of causal conditions. The use of QCA has rarely been reported in policy transfer studies, and is likely to offer conceptual and paradigmatic challenges to its adoption in some settings.

Finally, before implementing ODA projects in overseas countries, it is necessary to consider whether sufficient conditions apply for these projects to be conducted satisfactorily. The analysis results presented here show that if the one of the five specified conditions is not met at the site, the success of the ODA project cannot be guaranteed. In addition, it is necessary for policymakers engaged in the ODA projects to place more emphasis on the three prime implicants minimizing solutions for the successful implementation of the projects in overseas countries.

\section{Acknowledgements}

This work was supported by the National Research Foundation of Korea Grant funded by the Korean Government (NRF-20161A5A2A03927173) 


\section{References}

[1] The Economist (2014) Rural development in South Korea [article], 6 December.

[2] Asian Development Bank (2012) Sharing Knowledge on Community-Driven Development. Manila: ADB.

[3] Saemaul Movement Training Center. (2007). Textbook for the Saemaul Undong Education..Suwon, Korea.

[4] Kyungwoon University (2008) Theorising 21st Saemaul Undong Movement and Developing the Practical Tasks. Kyungwoon University Saemaul Academy.

[5] Kim, J. S., Choi, Y. H., Kim, J. H. and Kang, J. H. (2006) The Saemaul Undong Movement Revisted: Analysis of the Success Factors Affecting it and Suggestions for Revitalising It. Kyunggi Development Institute.

[6] Dolowitz, D. and Marsh, D. (2000) Learning from abroad: the role of policy transfer in contemporary policy making, Government, 13(1), 5-24.

[7] Benson, D. and Jordan, A. J. (2011) What have we learned from policy transfer research? Dolowitz and Marsh revisited, Political Studies Review, 9, 366-78.

[8] Greener, I. (2002) Understanding NHS reforms: the policy transfer, social learning, and path-dependency perspectives, Governance, 15(2): 161-83.

[9] Rose, R. (1991) What is lesson-drawing? Journal of Public Policy, 11(1), 3-30.

[10] Rose, R. (1993) Lesson-Drawing in Public Policy: A Guide to Learning across Time and Space. Chatham: Chatham House.

[11] Coleman, J. S., Katz, E. and Menzel, H. (1966) Medical Innovation: A Diffusion Study. Indianapolis, IN: Bobbs-Merrill.

[12] Walker, J. (1969) The diffusion of innovations among the American states, American Political Science Review, 63(3), 880-99.

[13] Collier, D. and Messick, R. E. (1975) Prerequisites versus diffusion: testing alternative explanations of social security adoption, American Political Science Review, 69(4), 1299-315.

[14] Rogers, E.M. (1995) Diffusion of Innovations. New York, NY: The Free Press.

[15] Obinger, H., Schmitt, C. and Starke, P. (2013) Policy diffusion and policy transfer in comparative welfare state research, Social Policy \& Administration, 47(1), 111-29.

[16] Dolowitz, D. and Marsh, D. (1996) Who learns what from whom: a review of the policy transfer literature, Political Studies, 44, 343-57.

[17] Evans, M. (2009) Policy transfer in critical perspective, Policy Studies, 30(3), 243-68.

[18] Stone, D. (1999) Learning lessons and transferring policy across time, space and disciplines, Politics, 19(1), 51-9.

[19] Page, E. (2000) Future Governance and the Literature on Policy Transfer and Lesson Drawing. Paper prepared for the ESRC Future Governance Programme, Britannia House, London, January 28.

[20] Dolowitz, D. (2003) A policy-maker's guide to policy transfer, Political Quarterly, 74(1), 101-9.

[21] Marsh, D. and Sharman, J. (2009) Policy diffusion and policy transfer, Political Studies, 30(3), 269-88.

[22] Department for International Development (2009) Political Economy Analysis: How to Note. London: DFID.

[23] Choi, O. C. (2013) Analysing the research trends in Saemaul Undong and establishing its Studies as an academic discipline, Korean Journal of Local Government and Administration Studies, 27(1), 61-92.

[24] Zeng, J. (2013) What matters most in selecting top Chinese leaders?, Journal of CHIN POLIT SCI, 18: 223-39.

[25] Ragin, C. (2000) Fuzzy-Set Social Science. Chicago, IL: University of Chicago Press.

[26] Poveda, S. (2013) Configurational Comparative Methods: Qualitative Comparative Analysis and Related Techniques. Thousand Oaks, CA: Sage. 
[27] Rihoux, B. (2006). Qualitative comparative analysis (QCA) and related systematic comparative methods: recent advances and remaining challenges for social sciences research. International Sociology, 21(5): 679-706.

[28] Wiechula, R. (2012) Assessing the robustness of crisp-set and fuzzy-set QCA results, Sociological Methods and Research, 40(2), 391-408.

[29] Donnelly, F. (2013) An example of qualitative comparative analysis in nursing research, Nurse Researcher, 20(6), 6-11.

[30] Soh, J. W. (1995) A Study of Principles and Achievements of the Saemaul Undong in Regional Development. Geography Studies

[31] Wiechula, R. (2013). An example of qualitative comparative analysis in nursing research. Nurse Researcher, 20 (6), 6-11. 